\title{
Electrochemical homo-coupling of benzyl halides on a powder cathode in a cavity cell
}

\author{
Renato A. da Silva*, Ronny F. M. de Souza, Madalena C. C. Areias, Marcelo Navarro \\ and Lothar W. Bieber
}

Departamento de Química Fundamental, CCEN, Universidade Federal de Pernambuco

*renatoagtsilva@gmail.com

Keywords: cavity cell, benzyl halides, solvent-free.

\section{INTRODUCTION}

The main challenge in organic synthesis is the formation of new $\mathrm{C}-\mathrm{C}$ bonds in order to construct more complex carbon skeletons in a defined arrangement. In contemporary electrochemical publications, such $\mathrm{C}-\mathrm{C}$ couplings are still a minor subject ${ }^{1}$. Herein we reported an application of a new electrochemical cell which uses graphite powder in the cathode cavity combined with an aqueous anolyte $^{2-4}$ to promote the dimerization of benzyl halides in good yield.

\section{RESULTS AND DISCUSSION}

Explorative voltammetry of benzyl chloride (1a) and bromide (1b) using the same electrolytic cell with very slow scan rates ${ }^{2-4}$ in cathode of graphite indicated reduction potentials of the -1.40 and -1.32 $\mathrm{V}$ (vs. $\mathrm{Ag} / \mathrm{AgCl}$, saturated $\mathrm{KCl}$ ) for producing toluene (2) and bibenzyl (3). On this silver-doped electrode material the peak potential was displaced to -0.88 for $1 \mathrm{a}$ and $-1.07 \mathrm{~V}$ to $\mathbf{1 b}$. Proper choice of controlled potential, catalyst and leaving group allows highly selective dimerization (Figure 1).

$$
\begin{aligned}
& \underset{1}{\mathrm{PhCH}_{2} \mathrm{X}} \underset{\mathrm{C} / \mathrm{H}_{2} \mathrm{O}}{\stackrel{\mathrm{ne}^{-}}{\longrightarrow}} \underset{2}{\mathrm{PhCH}_{3}}+\underset{3}{\mathrm{PhCH}_{2} \mathrm{CH}_{2} \mathrm{Ph}} \\
& \text { 1a: } X=C l \\
& 1 b: X=B r
\end{aligned}
$$

\section{Figure 1. Electrochemical dimerization of benzyl halides}

For both halides with method $A$, the yield of 3 increased continuously from more negative to less negative potentials, reaching $81 \%$ in the case of $\mathbf{1 b}$ (entry 4). Consequently, 2 was favored by more cathodic potentials and was the main product in all experiments with 1a (entries 1-3). The effect of silver catalysis (method B) in controlled potential electrolyses also was observed. No clear difference in the reaction rate and conversion of $\mathbf{1} \mathbf{a}$ and $\mathbf{b}$ was observed. Also the product distribution became very similar with maximum yields of dimer 3 of 64 and

\begin{tabular}{|c|c|c|c|c|c|}
\hline${ }^{\mathrm{a}}$ Entry & $\mathrm{PhCH}_{2}-\mathrm{X}$ & ${ }^{b}$ Method & ${ }^{c} E / V$ & ${ }^{d} 2$ & ${ }^{d_{3}}$ \\
\hline 1 & $1 a$ & $A$ & $-1,0$ & 46 & 27 \\
\hline 2 & $1 a$ & A & $-1,2$ & 59 & 10 \\
\hline 3 & $1 \mathrm{a}$ & A & $-1,4$ & 91 & 8 \\
\hline 4 & $1 b$ & A & $-0,8$ & 1 & 81 \\
\hline 5 & $1 b$ & A & $-1,0$ & 24 & 73 \\
\hline 6 & $1 b$ & A & $-1,2$ & 48 & 49 \\
\hline 7 & $1 b$ & A & $-1,4$ & 46 & 39 \\
\hline 8 & $1 a$ & B & $-0,8$ & 13 & 59 \\
\hline 9 & $1 \mathrm{a}$ & B & $-1,0$ & 28 & 64 \\
\hline 10 & $1 \mathrm{a}$ & B & $-1,2$ & 64 & 24 \\
\hline 11 & $1 a$ & B & $-1,4$ & 55 & 35 \\
\hline 12 & $1 b$ & B & $-0,8$ & 11 & 79 \\
\hline 13 & $1 b$ & B & $-1,0$ & 14 & 80 \\
\hline 14 & $1 b$ & B & $-1,2$ & 25 & 69 \\
\hline 15 & $1 b$ & $\mathrm{~B}$ & $-1,4$ & 30 & 60 \\
\hline
\end{tabular}
$80 \%$, respectively, at $-1.0 \mathrm{~V}$ (entries 9 and 13).
Table 1. Electrochemical dimerization of benzyl halides

a General reaction conditions described in the references 2; Method $A=$ graphite, Method $B=$ graphite silver-doped; " (vs. $\mathrm{Ag} / \mathrm{AgCl}$ sat. $\mathrm{KCl}) ;{ }^{d}$ Chemical yield determined by $\mathrm{H}^{1} \mathrm{NMR}$

\section{CONCLUSION}

In summary, we demonstrated the synthetic efficiency of cavity cell in reductive homo-coupling of benzyl halides. The procedure eliminates organic solvents, supporting electrolytes and sacrificial anodes of traditional electrosynthetic methods and is characterized by experimental simplicity and low environmental impact.

\section{ACKNOWLEDGEMENTS}

The authors wish to thank CNPq and CAPES by financial support.

\section{REFERENCES}

${ }^{1}$ Yoshida, J.; Katoaka, K.; Horcajada, R.; Nagaki, A. Chem. Rev. 2008, 108, 2265.

Areias, M. C. C.; Navarro, M.; Bieber, L. W.; Diniz, F. B.; Leonel, E.; Cachet-Vivier, C.; Nedelec, J. Y. Electrochim. Acta, 2008, 53, 6477.

${ }^{3}$ Souza, R. F. M.; Souza, C. A.; Areias, M. C. C.; Cachet-Vivier, C.; Laurent, M.; Barhdadi, R.; Navarro, M.; Bieber, L. W. Electrochim. Acta, 2010, 56, 575

Souza, R. F. M.; Areias, M. C. C.; Bieber, L. W.; Navarro, M. Green Chemistry, 2011, DOI: 10.1039/C0GC00947D, Communication. 